\title{
The Effect of Formative Assessment With the Ilearn Method on the Improvement of Student Learning Outcomes
}

\author{
Laila Rahmi ${ }^{*}$ Rafika Oktova
}

\author{
${ }^{1}$ Bachelor of Midwifery, Medical of Faculty, Andalas University \\ ${ }^{2}$ Bachelor of Midwifery, Medical of Faculty, Andalas University \\ *Corresponding author.Email: lailarahmi@med.unand.ac.id
}

\begin{abstract}
Advances in science and technology and in the face of the Globalization Era have increased public demands for higher education including midwifery higher education. Blended Learning is a development of the e- learning learning model that allows lecturers to provide a more comprehensive learning experience for students, increase access and convenience for students in accessing learning materials, improve the quality of learning and reduce learning costs. Formative evaluation is an evaluation that is carried out when a particular product or program is being developed and carried out more than once with the aim of making improvements. Based on the results of student learning in the previous course block, it is known that most $(90.2 \%)$ students obtained unsatisfactory scores $(<65)$, so that the development of the method is expected to improve students' ability to master the material that has been obtained to prepare themselves. on the evaluation at the end of the block. In this study, the implementation of formative assessments carried out by the method of giving quizzes in each week of block learning carried out by utilizing the ilearn platform of the Andalas University Faculty of Medicine was considered very effective because it could increase student motivation to increase the quality and quantity of learning, students were more prepared to face exams. the end of the block, and help improve students' understanding of the material given each week.
\end{abstract}

Keywords: Formative Assessment, Ilearn, Learning Outcomes

\section{INTRODUCTION}

Advances in science and technology and the increasingly shifting of the world economy to a knowledge-based economy in the face of the Globalization Era, have increased the demands of society for higher education, including midwifery higher education.

Globalization shows that the boundaries between countries are getting thinner, the exchange of labor, products and information is very fast which encourages each country to be more competitive in seizing world markets. The Ministry of Health as a stakeholder with a vision of "Healthy society that is independent and just" becomes one of the references in formulating graduate competencies. WHO policy that plans patient safety as a program that must be implemented in the health sector. Currently, improving the quality of health personnel is a concern of various parties, which is seen as a national policy. One of the 4 main issues in the health sector is the fulfillment of strategic health personnel needs in remote areas.

Facing these challenges, it is necessary to guarantee and improve the quality of midwife graduates that can be done through several efforts, namely development and innovation of science and problem-based curricula, development of system-based midwifery education, to be able to improve performance and be able to adapt the main competencies of midwives and have a broad knowledge of knowledge.

Blended Learning is a development of the elearning model. With the existence of Blended Learning allows lecturers to provide a more comprehensive learning experience for students, increase access and convenience for students in accessing learning materials, improve the quality of learning and reduce learning costs. Blended Learning can combine face-to- 
face learning models with online learning. From the accessibility aspect, the application of the blended learning model allows lecturers to distribute learning materials and learning media online so that students can access them anywhere and anytime with an internet connection, access can be done via a laptop or via a smartphone. For the quality of learning, the application of the learning model improves the student experience through learning media in the form of text, audio, video, animation, or through online discussion forums [1].

The direction of developing educational technology today does not only focus on cognitive development but also emphasizes the development of affective abilities and attitudes. Therefore, it is necessary to develop a learning model that is able

To cover more comprehensive aspects. Limited time and access to learning materials are certainly not a major obstacle in improving student quality. By using a blended learning model that combines online learning and face-to-face learning, the effectiveness of learning can be achieved with good evaluation results [1].

According to Scriven (1991) in Badrujaman (2009), formative evaluation is an evaluation that is usually carried out when a particular product or program is being developed and is usually done more than once with the aim of making improvements [2]. Meanwhile Weston, McAlpine and Bordonaro (1995) in Badrujaman (2009) explain that the purpose of formative evaluation is to ensure the expected goals can be achieved and to make improvements to a product or program. This is in line with Worthen and Sanders (1997) in Badrujaman (2009) which states that formative evaluation is carried out to provide evaluative information that is useful for improving a program [2].

Formative assessment is an assessment process, which is used to obtain information and evidence of learning from students to plan the next instructional activity. Educators use formative assessment to improve teaching methods and feedback (feedback) in the teaching and learning process of students. Formative assessment also helps students to be more successful in summative assessment [3].

From the results of research conducted by Purnomo, YW (2013) on the effectiveness of formative assessment on student mathematics learning outcomes in terms of learning motivation, it was found that formative assessment-based learning was more effective than traditional assessment both in general and for each category of motivation [4].

The Pathology and Basic Pharmacology course is one of the courses carried out with a block system (Block 2.B) which must be studied by second semester students in the Undergraduate Midwifery Study Program, Faculty of Medicine, Andalas University. Students who take lessons in the Block 2.B course of
Pathology and Basic Pharmacology have the opportunity to understand the pathophysiology of disease, explain infection prevention and pharmacology of drugs used in midwifery practice. In this course block students will learn about immunology, basic pathobiology, infectious microorganisms, infection prevention and basic pharmacology with various learning activities.

The learning approach used is Student Centered Learning (SCL), its activities consist of PBL tutorials using the seven jump method, small group discussions on certain topics, clinical skills training, independent study, introductory lectures, plenary discussions and expert consultations if needed. Student assessment is carried out through exams at the end of the block using the ilearn system, assessment during tutorials and assessment of clinical skills. Thus mastery of the material in Block 2.B is important because it will provide a body of knowledge for students in carrying out their profession later as a midwife.

The learning approach used is Student Centered Learning (SCL), its activities consist of PBL tutorials using the seven jump method, small group discussions on certain topics, clinical skills training, independent study, introductory lectures, plenary discussions and expert consultations if needed. Student assessment is carried out through exams at the end of the block using the ilearn system, assessment during tutorials and assessment of clinical skills. Thus mastery of the material in Block 2.B is important because it will provide a body of knowledge for students in carrying out their profession later as a midwife.

Based on the Decree of the Dean of the Faculty of Medicine, Andalas University number 3323/UN16.02D/PP/2018 concerning Academic Regulations, the evaluation system is an assessment of the implementation and success of the learning process including: tutorial activities, clinical skills, group study, independent study and other academic tasks. . The evaluation is carried out by the block coordinator, clinical skills coordinator, the head of the study program, the vice dean of the academic division, the Quality Control Group, and the Medical Education Unit (MEU) Monitoring and Evaluation Division. The assessment system at the academic stage of education uses Absolute Norms, namely Benchmark Reference Assessments which require accurate and mature mastery to achieve the competencies specified in the curriculum. The minimum pass mark for the written test/ MCQ is a value of 55. Students are deemed to have passed the block concerned, if they get a complete final block score of at least 55, provided that the MCQ block test score is at least 55 [5].

The method development that will be carried out in this research is to conduct a formative assessment of students each week in the form of a quiz block that has 
never been done so far. This is done because based on the learning outcomes of students in the previous course block in the first semester, it is known that most $(90.2 \%)$ students get unsatisfactory scores $(<65)$, so that the current method development is expected to improve student abilities on the mastery of the material that has been obtained every week block week as a way to prepare for the evaluation at the end of the block which is carried out by the Computer Based Test (CBT) on ilearning conducted at the Computer Labor Faculty of Medicine, University of Andalas.

\section{Research purposes}

1. Developing learning methods in meeting graduate learning outcomes.

2. Knowing the difference in the achievement of student learning outcomes with the application of the development of learning methods to be carried out.

\section{OUTPUT ACHIEVEMENT STRATEGY}

\section{Development Method}

The learning development method that will be carried out is by holding a formative assessment in the form of a quiz to students every week from the 5 weeks that are available during block learning.

\section{Device Used}

The device used in this study uses the ilearn facilities at the Faculty of Medicine, Andalas University which can be accessed on the http://fk.ilearn.unand.ac.id/ page, so that the timing of the assessment can be carried out outside the student learning schedule without disturbing existing learning activities and can be accessed by all students wherever they are.

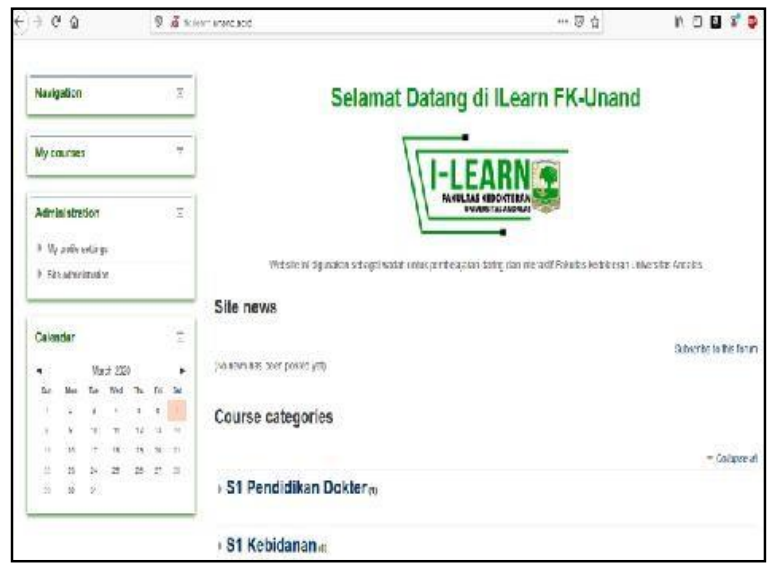

Figure 1. Home page Ilearn FK Unand

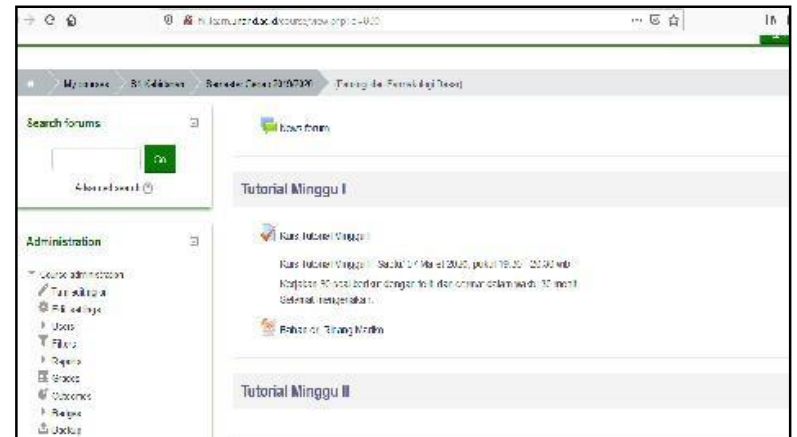

Figure 2. Block Quiz Page 2.B Basic Pathology and Pharmacology

\section{Implementation time}

Implementation of formative assessment with this quiz is carried out during Block 2.B learning of Basic Pathology and Pharmacology (6 weeks including 1 week of block examination) by conducting 5 assessments (each week of effective learning).

\section{DIVISION OF TASKS IN PREVIOUS TEACHING TEACHING}

The division of tasks in the previous teaching team was carried out by distributing a team of lecturers who taught each Introductory Lecture topic in Block 2.B of Pathology and Basic Pharmacology. The learning development method that will be carried out in this case is not related to the assignment of the lecturer who teaches the intended Introductory Lecture topic, but the provision of quiz questions made by the research team based on the material provided by the lecturer to students, then inputted into the ilearn system that has been designed.

\section{IMPLEMENTATION OF ACTIVITIES}

The learning development method used is to conduct formative assessments in the form of quizzes to students every week from 5 weeks during block learning using ilearn facilities, Faculty of Medicine, Andalas University which can be accessed on the http://fk.ilearn.unand.ac.id page. /, with the display shown below :

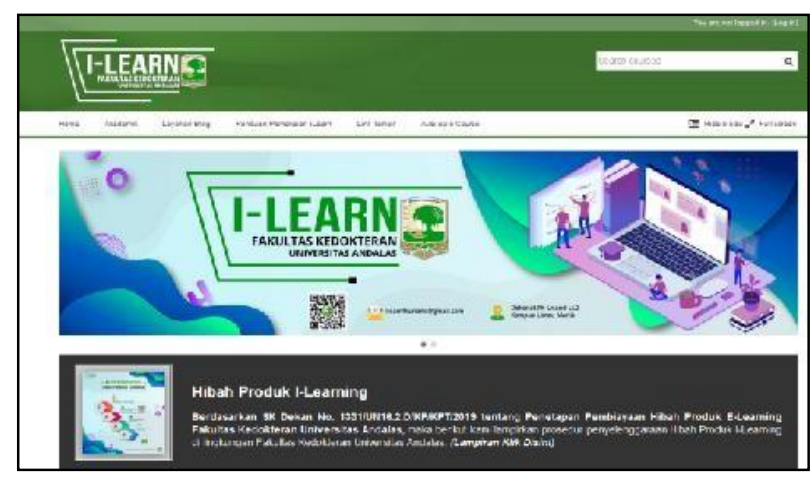

Figure 3. Page ilearn Faculty of Medicine Unand 
Furthermore, the page can be accessed on the Course Categories "S1 Midwifery" > "Even Semester 2019/2020" >> "Block 2.B (Pathology and Basic Pharmacology)" as shown in the following figure :

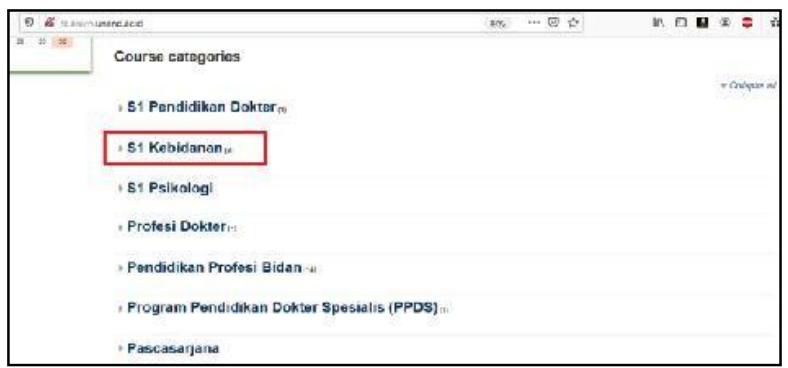

Figure 4. Option of S1 Midwifery Study Program in the Course categories

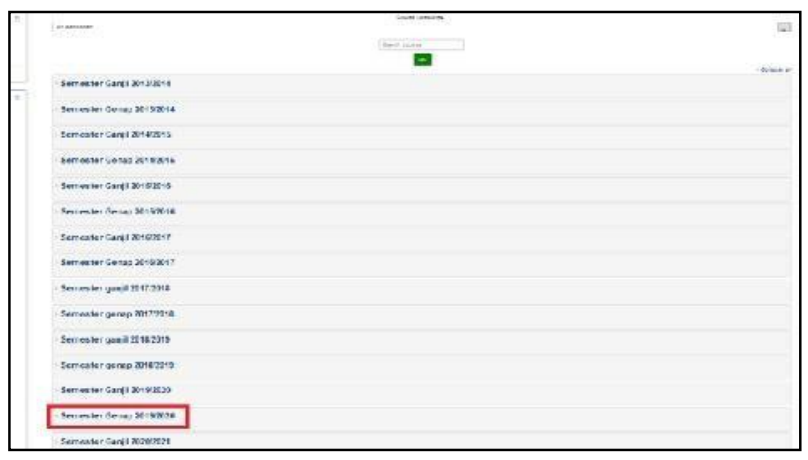

Figure 5. Semester Option on the S1 Midwifery Course

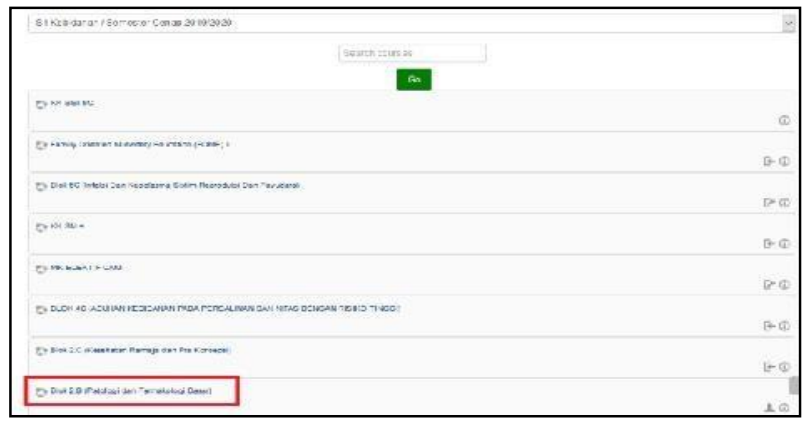

Figure 6. Option Block 2.B in the S1 Midwifery Course

So that the display will appear in several sections, including Block Introduction as shown below :

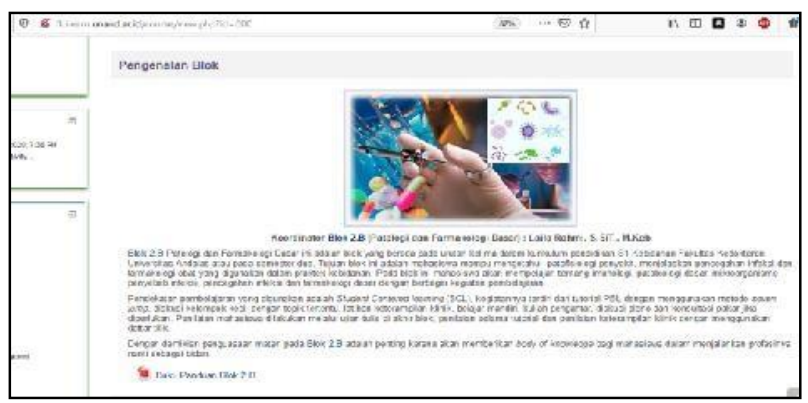

Figure 7. Block 2.B page view with several Sections

The application of learning methods that have been implemented can be described as follows:

1. Implementation of formative assessment with this quiz is carried out during Block 2.B learning of Basic Pathology and Pharmacology (6 weeks including 1 week of block examination) by conducting 5 assessments (each week of effective learning).

2. The implementation of the quiz that is carried out can be accessed under each section in each lecture week which is provided on the Block 2.B page :

a. Quiz I : Saturday / March 07 (Week I Block)

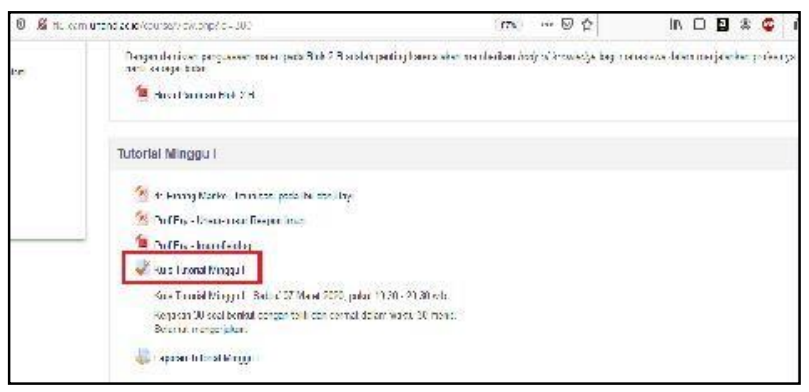

Figure 8. Choice of Quiz I on Week I

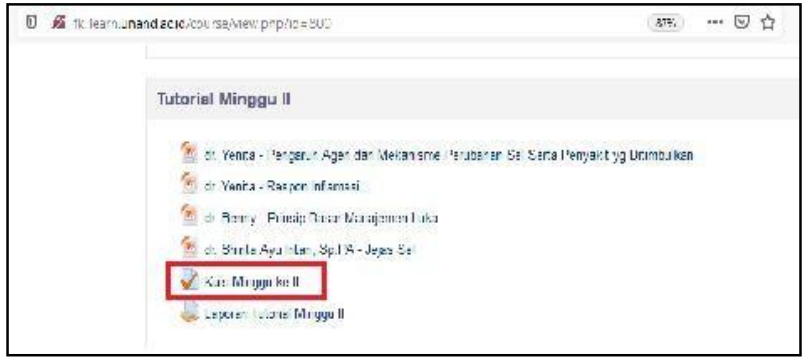

Figure 9. The First Quiz Implementation Page

b. Quiz II: Sunday / March 15 (Week IIBlock)

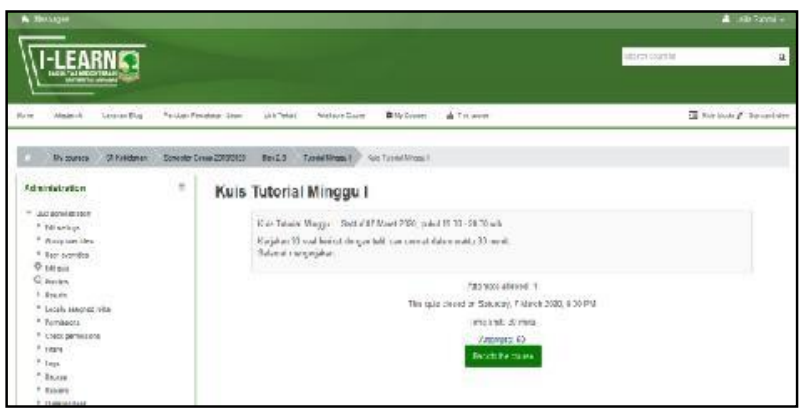

Figure 10. Choice of the 2nd Quiz on Week II 


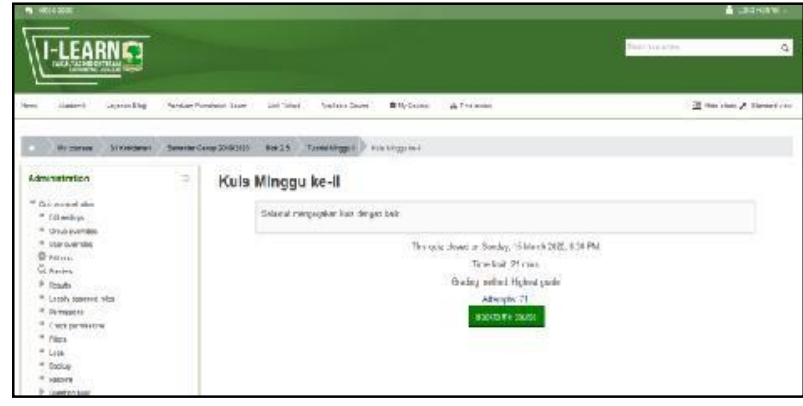

Figure 11. The Second Quiz Implementation Page

c. Quiz III: Monday / March 29 (Week IV Block)

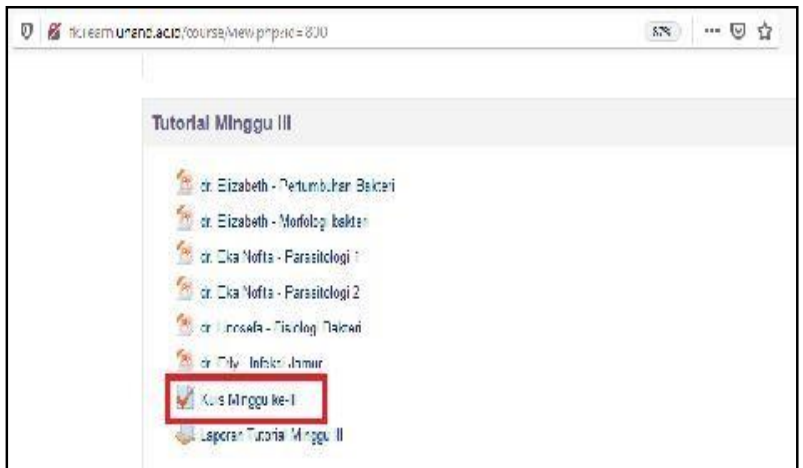

Figure 12. Choice of the 3rd Quiz on Week III

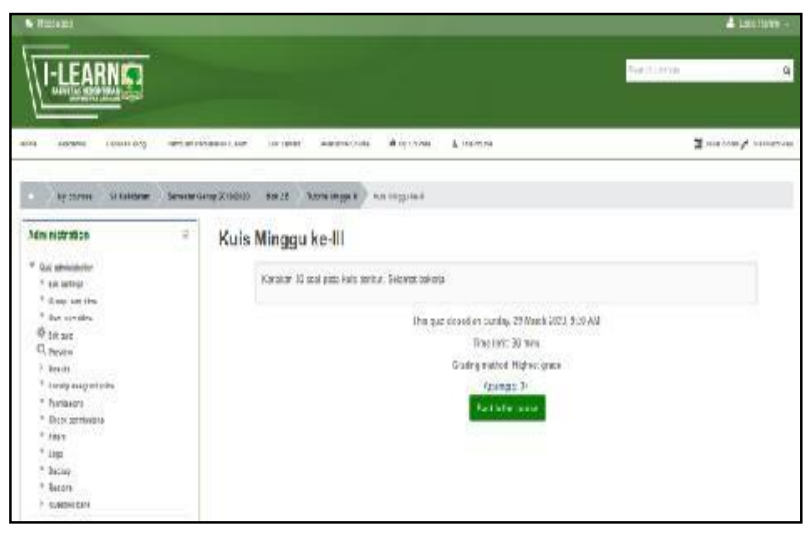

Figure 13. The Third Quiz Implementation Page

d. Quiz IV: Sunday / April 05 (Week VBlock)

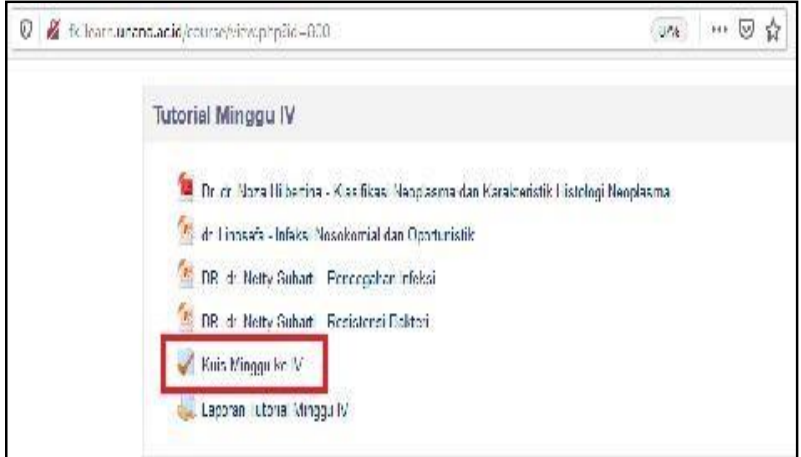

Figure 14. Choice of 4th Quiz on Week IV

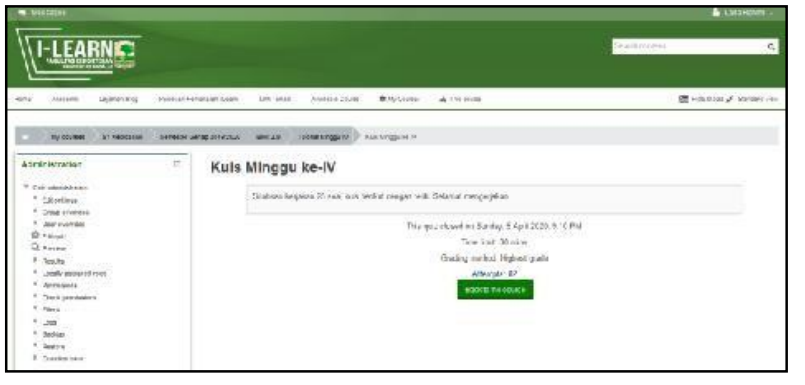

Figure 15. The Fourth Quiz Implementation Page

e. Quiz V: Tuesday / April 07 (Week VI Block)

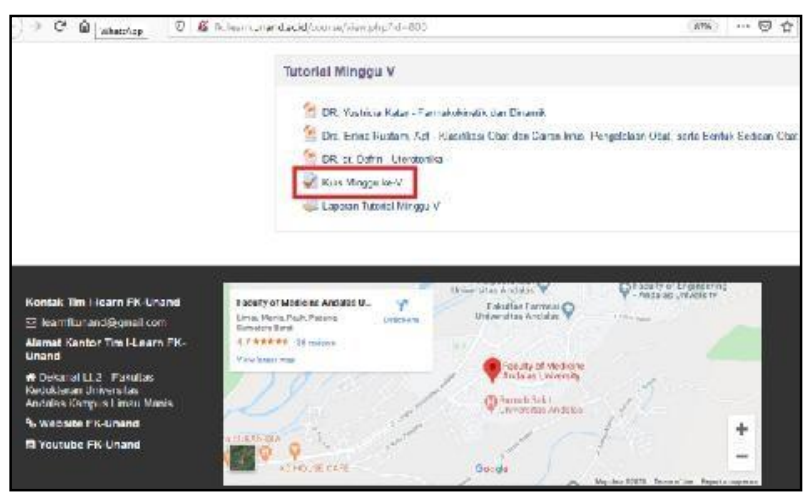

Figure 16. Choice of Quiz V on Week V

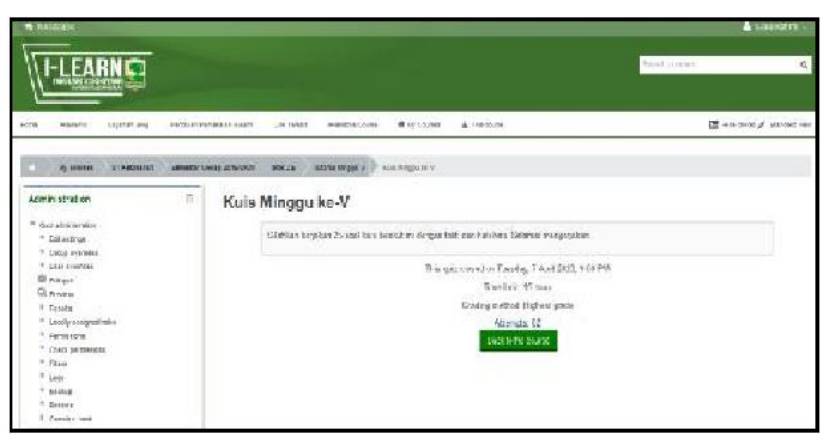

Figure 17. The Fifth Quiz Implementation Page

3. Block Examination Implementation: Thursday/ April 092020

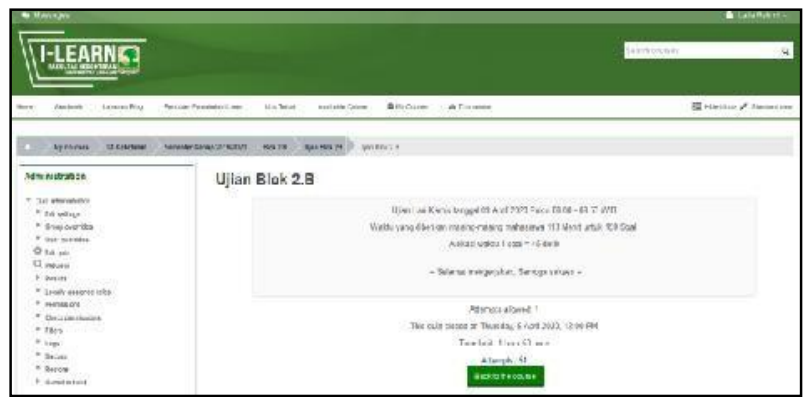

Figure 18. Block 2.B Examination Implementation Page 


\section{RESULTS}

Based on formative assessments with quizzes that are carried out every week, the effective learning process during Block 2 learning is Basic Pathology and Pharmacology :

\section{The spread of values at the end of the block}

Based on table 3 , it can be seen that during the implementation of formative assessments with quizzes that are carried out every week, there are 6 students who did not complete the assessment (red scores), so the processing was not included.

\section{a. Normality test}

The normality test is carried out to see the distribution of existing numerical data whether it is normally distributed or not. Normally distributed data is important as one of the requirements for performing statistical tests of the correlation test. The normality test carried out on the following data was carried out with the Shapiro Wilk test because the number of samples was less than 50. After the data transformation is carried out, the two variables of the quiz score and the final block score are normally distributed.

\section{b. Correlation Test}

Correlation test is used to analyze data statistically to see the relationship between two variables with numerical data. The results of statistical tests carried out can be presented as follows :

Table1. Pearson Correlation Test Results

\begin{tabular}{ll}
\hline & Final score \\
\hline Quiz scores & $\mathrm{r}=0,441$ \\
& $\mathrm{p}=0,002$ \\
& $\mathrm{n}=45$ \\
\hline
\end{tabular}

From table 1 it can be seen that the value of $p=$ 0.002 and the value of $r=0.441$, this indicates that there is a significant relationship between the quiz score (formative assessment results) and the final score (learning outcomes) with a positive relationship and moderate strength.

\section{Student response to the learning method developed}

The following is the conclusion of the responses given by students to the development of learning methods carried out, namely formative assessments with quizzes conducted every week, effective learning during Block 2.B learning of Basic Pathology and Pharmacology :

a. The quiz which is held every week requires students to study more regularly and continuously each week. b. Quiz implementation is considered to increase the quality of student learning because they have to repeat the learning material that has been given.

c. At first students admitted that they felt burdened by the quizzes that were held every week, but they became more prepared and maximal in facing the final block exam.

\section{DISCUSSION}

The results of the correlation statistical test presented in table 6 show that the value of $p=0.002$ and the value of $r=0.441$ indicates a significant relationship between the quiz score (formative assessment results) and the final score (learning outcomes) with a positive relationship and strength moderate.

Based on the results of research conducted by Selegi (2017), it was found that the results obtained from formative evaluation had an influence on the success of summative evaluation which was marked by an increase in the acquisition of student scores [6]. In line with the research conducted by Windani (2016) in his research on the implementation of formative assessment strategies to improve the mastery of concepts and habits of mind in high school students, it is suggested that there is an increase in students' mastery of concepts with high criteria for the implementation of formative assessments carried out. In addition, most students gave positive responses to the implementation of formative assessment strategies carried out in learning [7].

Ismail (2015) in his research also found that there were differences in the learning outcomes of groups of students who were given formative assessments at each face-to-face with the learning outcomes of groups of students who were given formative assessments for each competency standard [8]. Similar to the findings of research conducted by Putri (2015), there is a significant interaction effect between the learning approach and the formative test on student learning outcomes [9].

Learning is not a goal or an outcome but a process to achieve goals and learning is not only improving, but broader than that, namely experiencing. To maximize the learning and learning process, evaluation is needed. Formative evaluation aims to improve the learning process. While summative evaluation aims to determine the level of success of students [10].

Sudjana (2009) states that formative assessment is an assessment carried out at the end of the teachinglearning program to see the success rate of the teachinglearning process itself [11]. Formative assessment is oriented towards the teaching and learning process. In formative assessment, besides having a feedback 
function, there is also a diagnostic function to find out the weaknesses of students, so that efforts can be made to improve learning. Through the formative test, information about the absorption level of each student will be obtained. Formative testing is intended as an activity with the aim of providing feedback that can be used to plan or change instructions. Through formative tests, it allows educators to form effective instruction and thereby improve the learning outcomes of their students. This test is conducted to determine the extent to which students have understood the subject matter and also to find out the weaknesses that occur in the learning process, such as the accuracy of using teaching methods, learning media and evaluation systems used in the learning process. This formative test activity is carried out in parallel with the ongoing teaching and learning process, so that students and educators get the right information (feedback) about the progress that has been made so that the learning process can be refined to be better [12].

Formative assessment is a process used by teachers and students by providing feedback to adjust ongoing teaching and learning to improve the achievement of desired learning outcomes [13]. In his research, McMillan (2013) states that formative assessment can be used as self-assessment and reflection for students, because through formative assessments carried out during the learning process will allow an educator to respond to the learning of their students as an effort to improve their learning outcomes [14]. Formative evaluation aims to provide data that allows the adaptation of a new program sequentially during its development and implementation phases [15].

In this study, the formative assessment carried out by the method of giving quizzes every week of block learning is considered very effective because it can increase student motivation to increase the quality and quantity of learning. This is because students will repeat the learning material continuously and regularly every week to be able to take the quiz well. Based on the final goal expected from the implementation of formative assessments through quizzes carried out using the ilearn platform of the Faculty of Medicine, Andalas University, which is to improve student learning outcomes at the end of the block, formative assessment through this quiz can be applied to the implementation of other blocks because it can better prepare students for the exam. end of the block so that it gives maximum results. The implementation of this formative assessment can help improve students' understanding of the material provided by the lecturer by re-reading and studying the material provided, students can better prepare themselves for the block exam because they have studied well every week.

\section{CONCLUSION}

1. Formative assessment which is done by giving quizzes every week of block learning is considered very effective because it can increase student motivation to increase the quality and quantity of learning.

2. Implementation of this formative assessment can help improve student understanding of the material provided by the lecturer by reading and studying the material provided again.

3. Students can prepare themselves better for facing block exams because they have studied well every week.

\section{REFERENCES}

[1] Handoko dan Waskito, 2018. Blended Learning : Konsep dan Penerapannya. Lembaga Pengembangan Teknologi Informasi dan Komunikasi (LPTIK) Universitas Andalas. Padang.

[2] Badrujaman, Aip. 2009. Diktat Teori dan Praktek Evaluasi Program Bimbingan dan Konseling. Jakarta.

[3] Bakula, N. 2010. The Benefits of Formative Assessments for Teaching and Learning. Science Scope, 34(1). 37-43.

[4] Purnomo, YW, 2013. Keefektifan Penilaian Formatif Terhadap Hasil Belajar Matematika Mahasiswa Ditinjau dari Motivasi Belajar. Prosiding, Seminar Nasional Matematika dan Pendidikan Matematika FMIPA UNY. Yogyakarta.

[5] Surat Keputusan Dekan Fakultas Kedokteran Universitas Andalas nomor: 3323/UN16.02 D/PP/2018 tentang Peraturan Akademik.

[6] Selegi, SF. 2017. Model Evaluasi Formatif-Sumatif terhadap Motivasi Belajar Mahasiswa. Prosiding Seminar Nasional 20 Program Pascasarjana Universitas PGRI Palembang.

[7] Windani, DK. 2016. Implementasi Strategi Penilaian Formatif untuk Meningkatkan Penguasaan Konsep dan Habits of Mind Siswa SMA pada Materi Larutan Penyangga. Universitas Pendidikan Indonesia.

[8] Ismail Ilyas. 2015. Pengaruh Intensitas Penilaian Formatif terhadap Hasil Belajar IPA dengan Mengontrol Pengetahuan Awal Siswa. Jurnal Formatif 2(1) :58-70. ISSN: 2088-351x. Putri Ratu Ilma. 2015. Pengaruh Interaksi Pendekatan Pembelajaran dan Bentuk Tes Formatif terhadap Hasil Belajar Matematika. Jurnal Pendidikan dan Pembelajaran, Volume 22, Nomor 1, April 2015.

[9] Hamalik, Oemar. 2010. Proses Belajar Mengajar. Jakarta: Bumi Aksara. 
[10] Sudjana, Nana. 2009. Penilaian Hasil Belajar Mengajar. Bandung: PT. Remaja Rosdakarya.

[11] Cruickshank, Donald R., Deborah Bainer Jenkins, dan Kim K. Metcalf. 2006. The Act of Teaching. New York: The McGraw-Hill Companies Inc.

[12] McManus, S., Ed. 2008. Attributes of effective formative assessment. Washington, DC: Council of Chief State School Officers.

[13] McMillan, James H.; Venable, Jessica C.; and Varier, Divya. 2013. "Studies of the Effect of Formative Assessment on Student Achievement: So Much More is Needed". Practical Assessment, Research, and Evaluation: Vol. 18, Article 2. DOI: https://doi.org/10.7275/tmwm-7792.

[14] Linda Allal and Lucie Mottier Lopez, 2005. Formative Assessment of Learning : a review of publication in French. Formative Assessment Improving Learning In Secondary Classrooms ISBN-92-64-00739-3. OECD. 